\title{
COORDINATOR OF AUTOMATED LIBRARY SERVICES TO SERVE IOWA'S STATE UNIVERSITIES
}

Charles R. Sage, presently Vice-President and Director of SHARE Research Corporation, Santa Barbara, California, and formerly a senior systems analyst at the Ames AEC Laboratory at Iowa State University, has been named the new Coordinator of Automated Library Services for the three state universities of Iowa. Approved by the State Board of Regents, the unusual new position will be the first joint appointment for the three institutions and their libraries. Although Iowa's state university libraries have long engaged in cooperative activities, the joint appointment is designed to allow coordinated efforts in automation and to avoid duplication and control costs. Sage, with a wide background in computerization and information science, will engage in a study of automation needs and make recommendations for coordinated library systems development. Additional benefits are expected to be attained during the study as other non-automated operations are brought under analysis.

Operating from a central office at the Iowa State University library, Sage will share his time equally among the libraries of the University of Iowa, Iowa State and the University
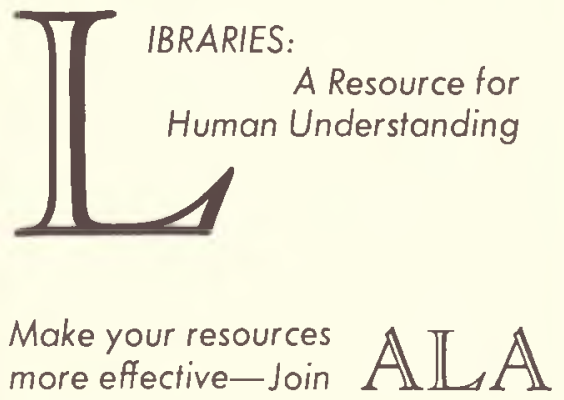

Celebrate

ALA Membership Day

October 21, 1969

Request

Free Membership Promotion

Materials

Membership Promotion Office

American Library Association

50 East Huron, Chicago, 111. 60611 of Northern Iowa. Computerized techniques are already in partial use by the Iowa State and University of Iowa libraries and computation and data processing centers at all three state campuses make administrative, research and teaching use of computers. Rapid national development in automation and the establishment of programs and data networks in many fields of knowledge will allow the three Iowa universities working in consort to coordinate systems and will assist in expanding their available resources to meet growing educational needs.

The new Coordinator will be responsible to the present Interinstitutional Committee of librarians and will work closely with library and campus computation and data processing center staff members. His salary and other expenses will be jointly shared by the three universities. While at the Ames Laboratory, Sage was the principal designer of the Ames Selective Dissemination of Information (SDI) System originally developed for scientists and engineers affiliated with the Ames Laboratory of the Atomic Energy Commission facilities. The SDI System provides a computerized current awareness service designed to increase literature searching capabilities for researchers. The Atomic Energy Commission has made the system available to the Iowa State University Computation Center and on July 1, 1969, this service will be extended to the campus faculty on a cost-sharing basis.

\section{CORNELL PROGRAM}

Cornell University libraries has started a program designed to foster a better understanding of the events of April 19 and following at Cornell. The libraries' Oral History Program and University Archives are cooperating in the project which will be undertaken in two phases. The first is the collection and organizing of written materials pertaining to events preceding and following the seizure of Willard Straight Hall by Cornell black students on April 19. The second phase is the use of oral history interviews to obtain pertinent data not obtained in the first phase. The materials are being collected with the expectation that the events will be of interest to scholars and the general public for many years, Gould P. Colman, director of the Oral History Program, said. Materials being sought include not only reports on dramatic events such as the Willard Straight seizure, but also reports on formal or informal meetings where the governance of the University was discussed. 